Volunteering in a school kitchen garden program: Cooking up confidence, capabilities and connections!

\title{
Volunteering in a school kitchen garden program: Cooking up confidence, capabilities and connections!
}

\section{Corresponding Author:}

Mardie Townsend, Faculty of Health, School of Health and Social Development, Deakin University, 221 Burwood Highway, Burwood, Victoria 3125, Australia

Email: mardie.townsend@deakin.edu.au

\section{Co-authors:}

Lisa Gibbs, Jack Brockhoff Child Health \& Wellbeing Program, The McCaughey Centre, School of Population Health, University of Melbourne Email: Igibbs@unimelb.edu.au

Susie Macfarlane, Faculty of Health, School of Psychology, Deakin University, 221 Burwood Highway, Burwood, Victoria 3125, Australia Email: susie.macfarlane@deakin.edu.au

Karen Block, Jack Brockhoff Child Health \& Wellbeing Program, The McCaughey Centre, School of Population Health, University of Melbourne, Victoria 3053, Australia Email: keblock@unimelb.edu.au

Petra Staiger, Faculty of Health, School of Psychology, Deakin University, 221 Burwood Highway, Burwood, Victoria 3125, Australia Email: petra.staiger@deakin.edu.au

Lisa Gold, Faculty of Health, Deakin Health Economics, Deakin University, 221 Burwood Highway, Burwood, Victoria 3125, Australia Email: lisa.gold@deakin.edu.au

Britt Johnson, Jack Brockhoff Child Health \& Wellbeing Program, The M cCaughey Centre, School of Population Health, University of M elbourne, Victoria 3053, Australia Email: brittamyjohnson@gmail.com

Caroline Long, Faculty of Health, School of Psychology, Deakin University, 221 Burwood Highway, Burwood, Victoria 3125, Australia Email: caroline.long@deakin.edu.au

Suggested running head: 'Volunteering in a school kitchen garden program'

\section{Acknowledgements:}

The authors would like to acknowledge the generosity of the school communities who committed considerable time and effort to participate in the evaluation. The funding provided by the Stephanie 
Alexander Kitchen Garden Foundation to conduct the evaluation is also gratefully acknowledged, as is the financial support the Foundation received for the evaluation from VicHealth, the Helen Macpherson Smith Trust, the Victorian Department of Education and Early Childhood Development, and Deakin University. Lisa Gibbs and Lisa Gold acknowledge the NHMRC Capacity Building Grant for Child and Adolescent Obesity Prevention and Lisa Gibbs the Jack Brockhoff Child Health and Wellbeing Program for salary and operational funding support.

For their assistance in the early stages of this project: Elizabeth Waters, Helen Bolger-Harris, Monica Green, Lucy Westerman, Michele Bell and Sing Kai Lo are also gratefully acknowledged.

(Arabic)

VOLU-D-11-00131R1

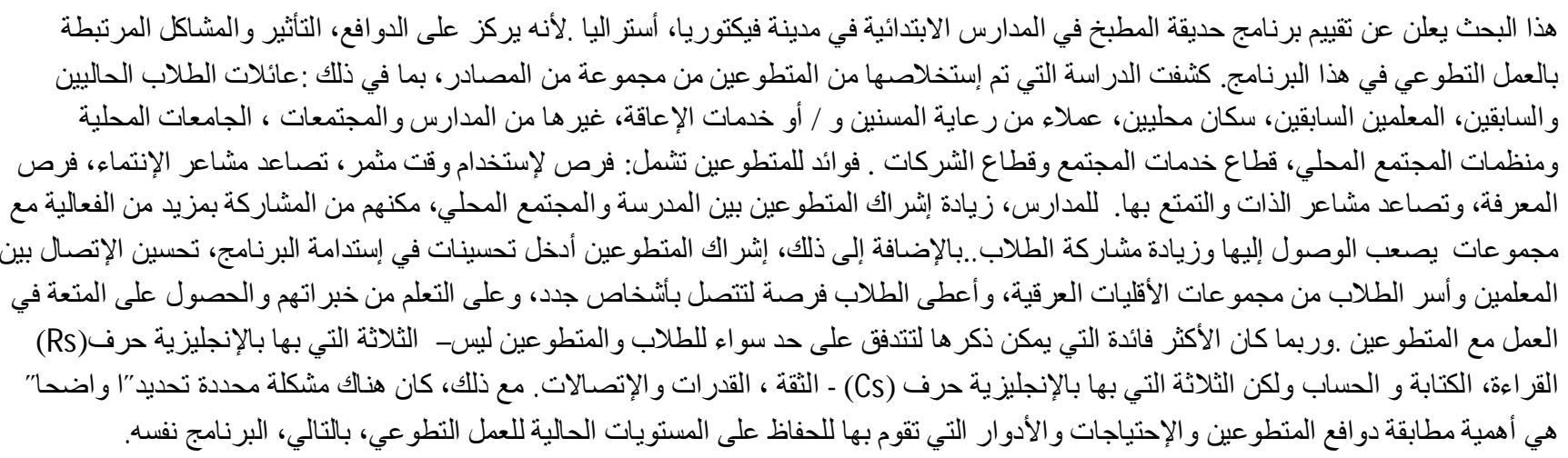

(Arabic)

VOLU-D-11-00131R1

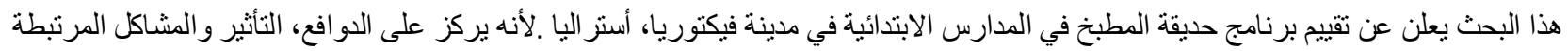

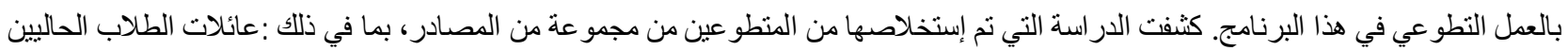

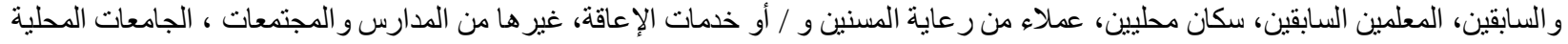

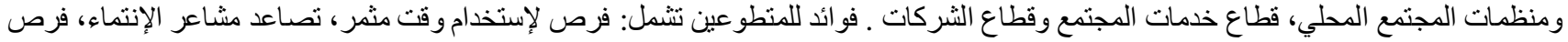


المعرفة، وتصاعد مشاعر الذات والتمتع بها. للمدارس، زيادة إثر الك المتطوعين بين المدرسة والمجتمع المحلي، مكنهم من المشاركة بمزيد من الفعالية مع

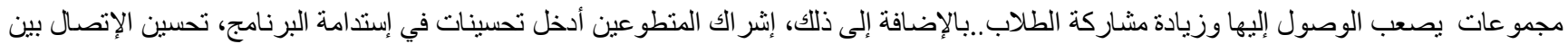

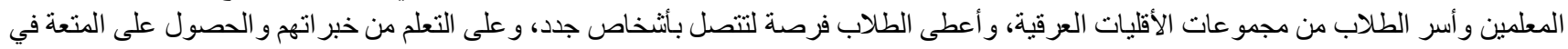

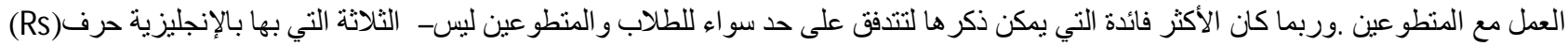

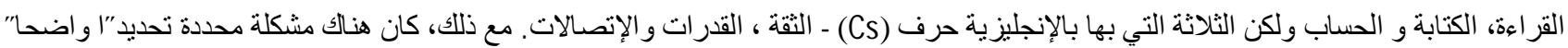

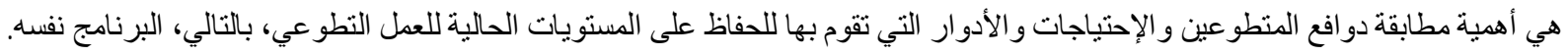

(Chinese)

VOLU-D-11-00131R 1

本文・告了・澳大利・ - 多利 - 州小学菜园 - 划的 - 估 - 果, 着重探 - 了自愿者参加 - - 划的 - 机、影响及存在的 - 。此次研究・ - , 自愿者来自各个 - 域, 包括 : 正在及曾・在学校就・的学生的家庭、前任教・、当地居民、老・・理 和/或残障服 - 的客 - 、其他学校和社区、本地大学、社区 - - 、社区服 - 部 - 和企 -。自愿者 - 得的益 - 包括 : 有成效 地利用・ - 的机会、更有・属感、学・的机会、更有自我价・感和愉悦感。就学校而言, 自愿者增 - 了学校与当地社区 的相互沟通，使学校能・更有效地与平- 不易接触到的・体・行交流，同・也增 - 了学生的参与精神。此外，自愿者的 参与・提高了・ - 划的可持 - 性, 增 - 了教 - 与少数族裔学生家庭的沟通, - 学生有机会 - - 原本不相 - 的人, 从自己

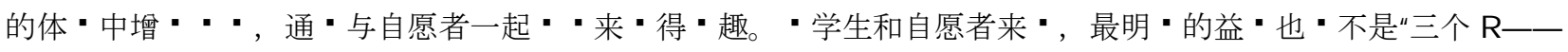
- (reading)、写 (w'riting) 和算数 (a'rithmetic) ”, 而是“三个 C - -

自信 (confidence)、能力（capabilities）和・系（connections）”。不・，我・也・・了一个明・的・・一一 重要的是 - 自愿者的・机和需求匹配他・扮演的角色, 以・持・有的自愿参与水平, - 而・持・划本身。

(French)

VOLU-D-11-00131R1

"Volunteering in a school kitchen garden program: Cooking up confidence, capabilities and connections!"

Cet article présente une évaluation d'un programme d'initiation à la cuisine dans des écoles primaires de l'Etat de Victoria, en Australie. L'analyse se concentre sur les motivations, les effets et les problèmes liés au bénévolat au sein de ce programme. L'étude révèle que les bénévoles proviennent d'origines très variées : familles d'anciens et de nouveaux élèves, ex-enseignants, voisinage, bénéficiaires de services aux personnes âgées et/ou handicapées, autres écoles et communautés, universités locales, organismes municipaux, secteur des services de proximité, et monde de l'entreprise. Les avantages que les bénévoles retirent du programme incluent : des opportunités d'utiliser leur temps de façon productive, un sentiment plus fort d'appartenance à un groupe, des opportunités éducatives, et un renforcement de leur sentiment d'estime de soi et une satisfaction accrue. Quant aux écoles, les bénévoles améliorent leurs interactions avec la communauté locale, leur permet d'agir de façon plus efficace auprès de groupes autrement difficiles à atteindre, et incitent les élèves à s'investir davantage. De plus, l'action des bénévoles accroît la durabilité du programme, améliore la communication entre les enseignants et les familles d'élèves issus de minorités ethniques, et donne aux élèves la chance de nouer des liens avec de nouvelles personnes, d'apprendre de leurs expériences, et de se divertir tout en travaillant avec les bénévoles. Peut-être que le gain le plus significatif pour les élèves comme pour les bénévoles ne réside pas dans les trois piliers classiques : lecture, écriture, arithmétique, mais dans les trois piliers que constituent confiance, aptitudes, et connections. Cependant, un problème apparaît clairement : il sera important de donner aux bénévoles un rôle qui correspond à leurs aspirations et leurs besoins afin de maintenir le bénévolat à son niveau courant, et par conséquent, le programme lui-même. 
"Volunteering in a school kitchen garden program: Cooking up confidence, capabilities and connections!"

In diesem Beitrag wird ein Küchengartenprogramm an Grundschulen im australischen Bundesstaat Victoria bewertet. Im Vordergrund stehen die Motivationen, Auswirkungen und Probleme in Verbindung mit einer ehrenamtlichen Mitwirkung bei dem Programm. Die Studie zeigte, dass die ehrenamtlichen Mitarbeiter aus einer Reihe unterschiedlicher Bereiche kommen bzw. diverse Hintergründe haben. Unter anderem sind sie Familienmitglieder derzeitiger oder ehemaliger Schüler, ehemalige Lehrer, Gemeindemitglieder und Kunden von

Dienstleistungseinrichtungen für ältere bzw. behinderte Menschen; manche kommen von anderen Schulen und aus anderen Gemeinden sowie von lokalen Universitäten, Gemeindeorganisationen, aus dem Gemeindedienstleistungssektor und dem Wirtschaftssektor. Durch die ehrenamtliche Tätigkeit erhielten sie die Gelegenheit, ihre Zeit produktiv zu nutzen. I hr Zugehörigkeitsgefühl wurde gestärkt, und die Tätigkeit brachte Lernmöglichkeiten, ein erhöhtes Selbstwertgefühl und Freude mit sich. Die Vorteile für die Schulen waren, dass durch die ehrenamtlichen Mitarbeiter das Zusammenwirken zwischen innen und den Gemeinden gefördert wurde, sie sich effektiver mit schwer erreichbaren Gruppen auseinandersetzen konnten und das Engagement der Schüler erhöht wurde. Zudem führte die Involvierung ehrenamtlicher Mitarbeiter zu einer verbesserten Nachhaltigkeit des Programms und einer besseren Kommunikation zwischen den Lehrern und den Angehörigen von Schülern aus ethnischen Minderheitsgruppen. Die Schüler konnten neue Beziehungen aufbauen, aus ihren Erfahrungen lernen, und sie hatten Spaß an der Arbeit mit den ehrenamtlichen Mitarbeitern. Die bedeutendsten Vorteile für sowohl Schüler als auch ehrenamtliche Mitarbeiter waren vielleicht nicht die drei grundlegenden Fertigkeiten Lesen, Schreiben und Rechnen, sondern die drei Qualitäten Selbstvertrauen, Fähigkeiten und Verbindungen. Allerdings wurde deutlich herausgestellt, wie wichtig es ist, die Motivationen und Bedürfnisse der ehrenamtlichen Mitarbeiter bei den von innen übernommenen Rollen zu berücksichtigen, um das gegenwärtige Maß ehrenamtlicher Beteiligung und somit das Programm selbst zu erhalten.

(SPANISH)

VOLU-D-11-00131R1

“Voluntariado en un programa de huerto escolar: ¡creando confianza, capacidades y conexiones!”

El presente documento informa de la evaluación de un programa de huerto en escuelas primarias en Victoria (Australia). Se centra en las motivaciones, los impactos y las cuestiones asociadas al voluntariado en dicho programa. El estudio reveló que los voluntarios procedían de una gama de fuentes, incluidas: familias de estudiantes actuales y antiguos, antiguos profesores, residentes locales, clientes de los servicios para discapacitados y/o de atención a personas mayores, otras escuelas y comunidades, universidades locales, organizaciones de la comunidad, el sector de servicios comunitarios y el sector corporativo. Los beneficios para los voluntarios incluyeron: oportunidades para utilizar el tiempo de manera productiva, un aumento del sentido de pertenencia, oportunidades de aprendizaje y un aumento del sentido del disfrute y del propio valor. Para las escuelas, los voluntarios aumentaron el compromiso entre la escuela y la comunidad local, les permitió comprometerse más efectivamente con grupos a los que es difícil llegar y aumentó el compromiso de los estudiantes. Asimismo, la implicación de voluntarios mejoró la sostenibilidad del programa, mejoró la comunicación entre los profesores y las familias de estudiantes de grupos étnicos minoritarios, y ofreció a los estudiantes la oportunidad de relacionarse con personas nuevas, aprender de su experiencia y divertirse trabajando con los voluntarios. Quizás los beneficios más elocuentes derivados tanto a los estudiantes como a los voluntarios no fueron las tres $\mathrm{R}$ - lectura, escritura y aritmética, del inglés "reading, w-riting and a-ritmetic", sino las tres C - confianza, capacidades y conexiones. Sin embargo, una cuestión claramente identificada fue la importancia de ajustar las motivaciones y necesidades de los voluntarios a los papeles a desempeñar para mantener los niveles actuales de voluntariado y, por consiguiente, el propio programa. 
This paper reports on the evaluation of a kitchen garden program in primary schools in Victoria, Australia. It focuses on the motivations, impacts and issues associated with volunteering in the program. The study revealed that volunteers are drawn from a range of sources, including: families of current and former students, former teachers, local residents, clients of aged care and/or disability services, other schools and communities, local universities, community organizations, the community services sector and the corporate sector. Benefits to volunteers included: opportunities to use time productively, an increased sense of belonging, learning opportunities, and an increased sense of self-worth and enjoyment. For schools, volunteers enhanced engagement between the school and the local community, enabled them to engage more effectively with hard to reach groups and increased student engagement. In addition, the involvement of volunteers improved the sustainability of the program, improved communication between teachers and families of students from minority ethnic groups, and gave students the chance to relate to new people, to learn from their experience and to have fun in working with the volunteers. Perhaps the most telling benefits to flow both to students and to volunteers were not the 'three Rs - reading, w' riting and a'rithmetic' but the three Cs - confidence, capabilities and connections. However, a clearly identified issue was the importance of matching volunteers' motivations and needs with the roles they play to sustain current levels of volunteering and, therefore, the program itself.

\section{Keywords}

School kitchen garden program; volunteering in schools; school-community engagement; benefits and motivations of volunteers 


\section{Introduction}

Conceived by Australian chef and food writer Stephanie Alexander, the school-based Stephanie Alexander Kitchen Garden program in Australia is an innovative gardening and cooking program aimed at providing children with a pleasurable introduction to food education through growing, harvesting, preparing and sharing fresh, seasonal, healthy and delicious food. It is based on the belief that these hands-on experiences will positively influence the food choices, attitudes to environmental sustainability and working relationships of the children involved (Block et al., 2009). An important aspect of the kitchen garden program is that it engages parents and members of the local community in volunteering roles and activities. Without such involvement, many schools would struggle to establish and sustain the program, since government funding for it from the Victorian Government does not cover the full cost of the program. Indeed, the funds allocated to each school were intentionally less than was required to fully cover the costs of the program therefore the structure of the SAKG program includes the expectation of fundraising AND regular class- based volunteering from each school community.

The aim of this paper is to draw on a case study of this program to add to the body of knowledge of the motivations for, impacts of and issues associated with volunteering in school communities, with a specific focus on volunteering associated with school garden and kitchen programs.

The next section provides an overview of the existing literature on volunteering, its motivations, impacts and challenges. This includes literature relating to volunteering in schools and specifically to volunteering in school garden programs. This is followed by a description of the methodology for the evaluation study which forms the basis of this paper, the findings of the evaluation in regard to volunteers and volunteering, and a discussion of the 
implications of these findings for the schools, teachers, volunteers, students and the broader community.

\section{Literature review}

Over recent years, the importance of volunteers in the successful delivery of programs and services in many nations has been widely acknowledged. The capacity of many service organizations to function effectively without the contributions of volunteers is limited. In the USA, the contributions of time, skills and energy by volunteers have been valued at more than US $\$ 270$ billion (Rotolo \& Wilson, 2006a). In Britain, where $16.6 \%$ of the adult population is involved in volunteering (Ruiter \& De Graaf, 2006), an audit of public sector support for volunteering noted the very significant contribution of volunteers (Institute for Volunteering, 2005), and research by Scottish National Heritage calculated the value of the 91,000 hours per month contributed by volunteers to maintaining the natural heritage of Scotland at over $£ 14.2$ million per annum (Scottish National Heritage, 2007). Australian data (Australian Bureau of Statistics, 2011) indicates that between $36 \%$ and $38 \%$ of adults in Australia participated in voluntary work in 2010. In the education sector in Australia, "there are roughly five volunteers for every four paid workers" (Ross, 2011). These figures highlight the importance of volunteers and volunteering in Australia and particularly in Australia's education sector.

For parents of children aged less than 15 years, the focus of their volunteering is typically related to the education or extra-curricular activities of their children (ABS, 2008). However, research from the USA (Brent, 2000a) shows that, while the age of the majority of volunteers in schools is between 36 and 55 years and most have children at the school, there is a substantial proportion of older people without school-aged children who undertake volunteering in schools. This is supported by Australian data which show that $7.2 \%$ of female 
and approximately $3 \%$ of male volunteers in education and training are aged 65 years or older (ABS, 2008). Typically, the majority of volunteers in education and training in Australia are female (ABS, 2008). With recent figures showing approximately two-thirds of mothers of children aged 9-12 years involved in paid employment (ABS, 2010), the capacity to sustain the volunteer base of primary schools in Australia may be under threat.

This threat to volunteer levels may be compounded in areas of low socio-economic status. Research in the USA (Brent, 2000b p. 507) indicates that the distribution of volunteers in schools may not be equitable, with "lower levels of volunteer resources ... associated with higher poverty schools". This view seems to be affirmed in relation to Australia by the recent Gonski Report (Gonski et al., 2011 p. xxii) which recommends that "additional funding provided to schools to overcome disadvantage should be invested in strategies that ... encourage parent and community involvement".

\section{Motivations for volunteering}

To encourage parental and community involvement in schools, it is important to understand the factors motivating people to volunteer. Flick, Bittman and Doyle (2002) note that the motivations of people to engage in volunteering can be classified into two groups: altruistic motivations (i.e. those based primarily on helping others) and instrumental motivations (i.e. those based on self-interest). However, they go on to note that the distinction between the two is often unclear. The reality that elements of both underpin the actions of most volunteers is borne out by a study of US Meals on Wheels volunteers which showed that, while few offer their time in order to receive a tangible benefit, volunteers do have preferences as to the range of rewards available (Phillips \& Phillips, 2010).

Another view is that described in the Volunteer Function Inventory (VFI) which identifies 
six categories of motivations for volunteering, based on the functions they serve in satisfying the social and psychological goals of the volunteer (Clary \& Snyder, 1999). According to Anderson and Cairncross (2005), the six categories are:

1. Values: concern for others;

2. Understanding: opportunities to use existing skills or develop new skills;

3. Social: opportunities to sustain existing relationships or build new friendships;

4. Career: career enhancement opportunities;

5. Protective: opportunities to overcome the risks associated with one's own problems or with guilt over being more fortunate than others;

6. Enhancement: opportunities for personal growth and self-esteem.

A closer examination of this list, however, shows that category 1 could be considered much the same as the 'altruistic motivations' identified by Flick, Bittman and Doyle, while motivations 2 to 6 could be seen as more specific sub-types of their 'instrumental motivations' category.

Recent research focusing on volunteer firefighters in the US (Carpenter \& Myers, 2010) has highlighted a complex relationship between altruistic and instrumental motivations, particularly in terms of the impacts on maintenance of individuals' commitment to volunteering. The decision of existing volunteers to respond to a fire call (i.e. to commit time to volunteering) was found to be both positively and negatively influenced by extrinsic rewards such as small payments, with some volunteers "who care about being perceived as altruistic" (p. 919) being discouraged by such rewards.

The complexity of volunteer motivations and rewards is further highlighted by Phillips and Phillips (2010) who distinguish between 'tangible' and 'intangible' rewards as motivators. They classify tangible rewards as "rewards that an organization intentionally provides, 
including goods, services, or experiences", whereas intangible rewards are defined as "any positive outcome inherent in the work, including feelings of satisfaction, increases in selfesteem, and similar outcomes" (p. 14). This distinction indicates that the classifications offered by Flick et al. and by Anderson and Cairncross may, in fact, be usefully combined to identify three broad categories of factors motivating volunteers: altruistic, material and intangible. Whichever way they are classified, it is clear that the motivations of volunteers are diverse (Phillips \& Phillips, 2010).

The importance of understanding the motivations underpinning the participation of volunteers is emphasized by Flick et al. (2002 p. 19), who note that "motivation directly affects the activity levels and retention rates of volunteers". Studies have shown that volunteer retention is closely related to satisfaction, and satisfaction relates to motivations and expectations (ACOSS, 1996). This link is evident in the quote from Jarvis (2007 p. 2) that

Every potential volunteer will have a motivation for wanting to give time to your organization. Identifying these motivations will allow you to match the needs of the volunteer with those of the organization.

Such matching will contribute to the sustainability of volunteering and thus the sustainability of programs which are dependent on volunteers.

\section{Impacts of volunteering}

Volunteering has a range of positive impacts, including environmental, economic, social, psychological, health and education benefits. Impacts may be felt at individual, organizational, community or broader societal levels.

In social terms, in addition to volunteering itself being an indicator of high levels of social 
capital, volunteers have been found to be "more likely than non-volunteers to donate money, attend a community event or provide unpaid assistance to someone outside their household" (ABS, 2008 p. 3). Moreover, the ABS survey found that volunteers are more trusting of other people than are people who do not volunteer (ABS, 2008). A recent paper from O'Brien et al. (2011) also highlighted the potential for volunteering to act as a means of reintegrating marginalized people into society.

In addition to its social wellbeing benefits, volunteering also contributes to enhanced selfreported physical and mental wellbeing (O’Brien, Townsend \& Ebden, 2010), with Black and Living (2004) noting that volunteering resulted in increases in positive mood, confidence and self-esteem. Furthermore, Townsend (2006) highlighted the psycho-social benefits for children when hands-on environmental activities involved volunteers across the age range. In particular, this enabled children to widen their social circle and the findings indicated that children displayed increased levels of confidence as a result of interacting with other adults.

Volunteering is also beneficial to an individual's physical health. While environmental volunteering has been shown to increase levels of physical activity (Townsend, 2006), a study by Li and Ferraro (2006 p. 511) found that engagement in volunteer activities also slows "the pace of functional decline". The educational benefits of volunteering opportunities for lifelong learning provided by engagement in volunteer activities - have also been claimed to have spin-off wellbeing benefits at both individual and societal levels (Narushima, 2005).

As well as being one of the most common settings for volunteering, schools have been shown to benefit greatly from the presence and input of volunteers. For example, a British study of a program engaging 'corporate volunteers' in schools as part of a literacy enhancement 
program (Williams, Thorogood \& Jones, 2002) showed wide-ranging benefits including: improved student literacy standards; greater student confidence and enthusiasm for reading (96\% of literacy co-ordinators agreed that the volunteers had played an important role in this); the development of close bonds between volunteers and students, with many volunteers going beyo nd the scope of the original project to contribute in other ways to the students with whom they were working; and an ongoing commitment to the schools by the majority of volunteers involved. The project "was met with enthusiasm by all taking part and the outcomes of the project were overwhelmingly positive" (p. 376).

A study of 47 schools in 12 states of USA (Sheldon \& Epstein, 2002) found that student behavior improved when parents and community members were involved in the schools as volunteers. This study highlighted the importance of increasing "the overlap between home and school"' (p. 22). Tan and Goldberg (2009) also considered the overlap of school and home environments, and studied the links between parental involvement in schools and children's results and adaptation. They found that "high levels of parental involvement by at least one parent are positively related to children's adjustment to school".

Over recent years, the practice of school gardening has become increasingly popular (Skelly \& Bradley, 2007), with gardens used as a teaching tool in relation to nutrition, environmental education and science (Graham et al., 2005). However, while the educational benefits of school gardens are widely acknowledged (e.g. Skelly \& Bradley, 2007; Harrison, 2008; Kirby, 2008; Blair, 2009), this does not appear to be reflected in their funding. Ozer (2007 p. 849) noted that "most school gardens rely heavily on donations of funding, technical assistance, labor, and materials from school and community members". Moreover, Ozer observed that the assistance needed may entail involvement in classes, work at weekends and during holiday periods, without which the program may be unsustainable. This dependence 
on volunteer involvement and contributions is confirmed by other authors (e.g. Kirby, 2008; Blair, 2009; Harrison, 2008; Hazzard et al., 2011; Henryks, 2011). The difficulties posed by this are highlighted by Harrison (2008 p. 24) who notes: "For many schools, the biggest obstacle to food gardens is the labor required to establish and maintain them. Teachers do not have the time to shepherd a vegetable garden through a growing season that includes a lengthy summer break. And while parents are vital partners, they come and go". Similarly, Hazzard et al. (2011), reporting on models for school gardens in California, noted the importance of parent and community volunteers, and highlighted lack of long-term volunteers as a barrier to successful instructional school gardens.

While the literature on motivations for volunteering in general implies that there is a two-way flow of benefits from such activities, there is limited reference to this in the literature on school gardens. Ralston (2011 p. 17) suggests that gardens in general, including school gardens, act as "inter-generational bridges" by providing spaces and opportunities for children and adults to "deliberate, socialize and transfer ideas from one generation to the next". Adult volunteers play a key role in this interaction. One example of reciprocal benefits comes from Australian research (Cutter-Mackenzie, 2009) focusing on the use of a school garden to enhance learning about language, culture and environment. This research noted the contribution of parents and community volunteers as "gardening buddies". These volunteers - typically parents, guardians and grandparents who were new arrivals to Australia - were actively engaged in "a cultural learning exchange where (they) ...would share stories and information about gardening and their culture, and students would mentor their buddies in English language helping them to connect with others in their community" (Cutter-Mackenzie, 2009 p. 125). Henryks (2011 p. 581) also alludes to a two-way flow of benefits from volunteering in a school kitchen garden, though in this case through a much 
more diffuse (rather than direct) model of reciprocal exchange, with volunteers simply benefiting "unexpectedly" or to a greater degree than anticipated.

\section{Challenges to retention of volunteers in schools}

Sustaining parent and community volunteer engagement in schools is not always easy and "lack of support on the part of parents or volunteers" has been cited as a key factor in the discontinuation of school garden programs (Ozer, 2007 p. 849). Research has also shown that teacher attitudes are influential. For example, Kim (2009) found that negative attitudes of some teachers and schools towards parents from minority groups, particularly in relation to their capacity or efficacy, may pose barriers to their involvement. Given this, as well as cultural differences in attitudes to parental communication and involvement with their children's schools, it is not surprising that Huntsinger and Jose (2009) found that "European American parents volunteered more in schools [than Chinese American parents]".

Among the range of other factors posing a challenge to retention of volunteers in schools are: parents who are in paid employment and are therefore not easily able to take time off to volunteer; parents with small children who may not have access to child care to enable them to volunteer; and the inconvenience, time and cost associated with the requirement to undergo police checks and/or working with children checks (Drummond, 2008).

Nevertheless, school garden programs offer an opportunity for schools to engage with the broader community, to form a partnership which "fosters ownership for the school property and encourages adult volunteerism and participation" (Berlinic, 2006 p. 15), bringing benefits to the school, the community and the individuals involved.

This paper will use these review findings as a basis for interpreting the qualitative data 
pertaining to volunteers from focus group discussions and interviews with SAKG program volunteers, parents, teachers and principals.

\section{Methodology}

This paper reports on the findings arising from the qualitative data component of a mixed methods research project conducted between 2006 and 2009. A description of the full project and its methods can be found in Gibbs et al. (2012). At the time the project began, a total of 22 primary schools were involved in the SAKG program. From these, a stratified random sample of six schools was selected for the evaluation, and these were matched with six comparison schools not involved in the program. During the data collection period (2007 to 2009), 770 children, 562 parents, 93 teachers and 17 volunteers participated in the evaluation.

The total number of volunteer hours contributed on one-off and ongoing bases by all volunteers (not only those involved in the evaluation) were reported by each participating school, although detailed data on the socio-demographic characteristics of volunteers were not recorded. Over the first two years of the program, an average 3,287 hours of volunteer time were invested in the program; valued at the 2009 average Australian wage rate this represents over $\$ 140,000$ of investment per school.

\section{Description of participants and procedures}

Focus group discussions were held between August and November 2008 with sample groups of teachers, parents and volunteers at two rural and two urban schools participating in the evaluation of the SAKG program and with two groups of children at each of six schools participating in the evaluation. All classroom teachers from grades three to six (children aged 8 to 12 years) were invited via the school principal or administration staff to attend the focus group discussions. Parents and volunteers were invited to attend the focus group discussions 
through notices placed in the school newsletter and through letters distributed to them by the school. Children were recruited from amongst those whose parents had already consented to their participation in the evaluation. Teachers were asked to select children who were happy to speak to the researchers and who would represent a range of year levels and experiences of the program. In addition, all principals and kitchen and garden specialist staff were interviewed at each of the six participating schools.

A total of twenty-six teachers participated in four focus groups. One assistant principal, one ICT (information and communications technologies) specialist teacher and one physical education teacher took part and the rest were all classroom teachers of grades three to six. Parent and volunteer focus groups were conducted at the same four schools. At one school, where low numbers of parents (all of whom were also volunteers) indicated their intention to attend, the parent and volunteer group discussion was combined. An additional interview with a parent volunteer was held at a fifth school not initially selected for focus groups, to capture data on that school's particularly innovative volunteer program. A total of seventeen volunteers, nine of whom were parents at the school, took part and twenty other parents participated in focus group discussions. One hundred and twenty-four children shared their experiences in twelve groups at the six participating schools.

Focus group discussions and interviews were semi-structured, following the same basic schedule with minor modifications where relevant for each group. Questions focused on participants' expectations and experiences of the program, changes in the school and home environment, impacts on individuals and communities, highlights and areas for potential improvement, most important outcomes and whether or not they would recommend the program to other schools. Interviews with school principals included questions about school 
demographics and program sustainability.

QSR NVivo software ${ }^{\mathrm{i}}$ was used as a data management tool for handling the large quantity of data contained in transcripts of focus groups and interviews. Thematic analysis was performed in which data were coded to identify emerging themes and patterns which were then categorized and analyzed according to their relationship to research questions.

\section{Participant observation}

Cooking and garden class observations were conducted at three time-points over the course of the program. One researcher visited each of four schools on the first round and passively observed a cooking and garden class on each occasion. The researcher kept written notes of observations during the class. In the second round and third rounds, the researcher observed classes and then discussed the observations with the specialist teacher. This provided an opportunity to gain the teacher perspective and to clarify observations made by the researcher, for example in relation to different supervision styles among the volunteer support teams. Descriptive data of the setting, the attitudes, the behaviors, the interactions, the conversations, the 'transitions' (e.g. from lacking confidence to having it; from apathy to interest to enthusiasm) were recorded by the researcher in written notes and drawings. Additional field diary notes were kept of researcher reflections on the possible meanings and explanations for what was observed and queries concerning issues that needed further clarification.

\section{Results}

Where the data in this section is drawn from focus groups, it is not possible to identify which individuals made specific comments. However, the breadth of data sources is indicated by quotes from individual volunteers, parents and children being identified by school (Sx), and 
quotes from individual interviews being identified by category (PR for principal, $\mathrm{T}$ for teacher) and number.

\section{Profile of volunteers}

The profile of volunteers involved in the program included parents and grandparents of current students, as well as former students, the parents of former students, former teachers and others who have had no past or current formal connection with the school. Other sources of volunteers included: a local aged care facility whose residents became involved as volunteers, SCOPE Australia whose adult clients with disabilities were involved with one school, 'sister communities' (schools and communities from elsewhere in Victoria who were linked in some way to the communities in which the schools were situated), local universities, community organizations (e.g. Rotary, the Ardoch Youth Foundation ${ }^{\mathrm{ii}}$ ), the community services sector (e.g. local police officers) and the corporate sector (e.g. ANZ bank employees).

In one school with a high level of cultural diversity within the school population, some difficulties were experienced in gaining community input (including recruitment of volunteers). However, the view of the principal (PR2) was that socio-economic disadvantage was more likely than cultural difference to be the primary barrier to volunteering. Indeed, the principal considered the involvement in volunteering by several Vietnamese parents as an important flow-on benefit of the program.

\section{Motivations/process of becoming and being involved}

The process of volunteer recruitment varied from school to school, as did the degree of success in achieving the level of volunteering necessary/required to implement the program. Strategies for volunteer recruitment included invitations in local newspapers, posters around the school premises, publicizing of volunteer opportunities through families of children at the 
school, and direct recruitment via telephone. One volunteer saw an advertisement in the local newspaper and responded (S4). Another volunteer (S2) stated:

I saw an ad by the Ardoch [Youth] Foundation and I particularly wanted to do some volunteer work in a primary school. I wanted to do it in the western suburbs, so Ardoch trained me and sent me out here.

Several parent volunteers noted that they had been asked by their children to volunteer in the program, while others were keen to see the program established and/or sustained in their children's school.

One school principal (PR2) noted that the program "expects" parent involvement, implying that once the school had agreed to adopt the program it was an obligation of parents to volunteer when available. While this was not referred to by other principals, the concept of ‘compulsory volunteering' was raised by one of the parent volunteers (P3).

Just as processes of recruitment varied, volunteers' motivations varied also, but the motivations of most volunteers seemed to focus on four main elements: support for the program (associated with concern about children's diets); support for the school and what it was trying to achieve; the opportunity to use their skills; and the opportunity to benefit personally from the experience. While there was some relationship between the process of recruitment and the motivations of volunteers (for example, recruitment of volunteers from among the parents of children at the school was commonly associated with the motivation 'support for the school and what it was trying to achieve'), the motivations of volunteers varied even within particular recruitment processes. 
To some degree, the roles undertaken by volunteers reflected their interests and/or skills. The garden specialist at one school (T2) commented: “one (volunteer) is a horticulturalist - a very useful resource". At another school(S4), a volunteer with severe sight-impairment (and otherwise unconnected to the school) reported huge enjoyment from volunteering in the garden, though did not think she would be "safe" in the kitchen. However, while some volunteers may have limited their involvement to their area of interest, others may have initially engaged in that way but later branched out. One volunteer (S4) commented: "we just alternate the kitchen and the garden. I preferred originally to just be doing the gardening, but this year I've actually really loved the cooking".

An older volunteer (with no direct connection to the school in which she was involved) who had responded to a newspaper advertisement for volunteers, highlighted an important role for volunteers, reflecting on the differences between the role of parents when her children had been young and modern parenting:

The children today, the parents don't have much time to spend with them ... so they need someone in the school who will spend time with the children: to talk to them, to laugh with them, to teach them "this is a tomato, a carrot and this is celery and that is sugar and that is salt $\square$; learn manners at the table. (S4)

\section{Impacts of volunteers and volunteering:}

Volunteers and volunteering have significant impacts on both the organizations in which they are involved and on individuals. Within the SAKG program, volunteering can be seen to impact on: the volunteers themselves, schools, the program itself, teachers and students.

1. Impacts on volunteers: 
It is clear from the data collected through interviews and focus groups that the volunteers who participated in the kitchen garden program gained many benefits from their involvement. One of the main benefits identified by volunteers was that of 'being valued'. One volunteer (S4) stated:

I was walking down the street... and a little boy was on his bike doing wheelies and after a little while he shouted "She's from the kitchen garden Mum!" and I thought "I really am a local”.

The same person went on to say: "I treasure the boy on the bicycle who said "she's from the kitchen garden Mum” because I feel valuable”.

A similar feeling was expressed by another volunteer (S5), who observed:

There have been a couple of times I haven't been able to come and one of the girls goes “where were you yesterday? We missed you!” and it just makes you feel appreciated and you are not doing it for nothing - you get benefits from it in the long run.

Others described it as 'feeling useful'. One (S4) said:

it makes me useful. It's something that is a good feeling, not staying at home waiting to die.

Another (S2) commented that "at a previous volunteer job I didn't feel needed enough". 
The ongoing recognition and support of the school community for volunteers and their contributions was highlighted as a key aspect of the sustainability of the program. A related issue is that of becoming a recognized part of the school community - part of a social network. One volunteer (S4) commented: "You get to meet other people and whilst you are busy you get to have a bit of a chat".

From another school(S5), several volunteers commented on the sense of belonging they felt. One said:

It just feels so comfortable; it's the only school I've been to that you can walk in and say "Hi, Hi, Hi" and the kids speak to you and the teachers speak to you. It's good.

Another (S5) commented:

I think we were a bit hesitant to come and volunteer sometimes maybe because most places that you volunteer you have little groups but in here it is completely different. You are made to feel welcome in all aspects of the school; it makes it a lot easier I think and it just grows and grows and grows.

Other impacts on volunteers related to training and skill development, changes to attitudes and confidence, and time.

Volunteers from one school (S5) which hosted adult education courses highlighted the benefits they gained through having access to training courses such as food handling, first aid, coffee making, computer skills and volunteering skills. One volunteer summed it up in the following statement: 
I try to encourage people to come and do them [the courses] because it's something you can fall back on later in life; like the food handling course got me a job at the canteen because I had that under my belt.... so the bigger picture is you're not just volunteering when you're helping. It will benefit you somewhere along the lines as well.

Others highlighted less formal acquisition of skills and knowledge - the correct way to hold a chef's knife, awareness of foods previously unknown, gardening techniques and the like:

I've learnt a lot about gardening in general - what are plants and what aren't plants. Just in the germinating things, the compost - I didn't know how to build a compost [heap]; the worm farm, for instance - I didn't know there was such a thing as worm juice. It's just given me a better knowledge of gardening. (S5)

Not surprisingly, given this increased knowledge and skill, volunteers highlighted a change in their attitudes and confidence, both in relation to food or gardens, and more broadly. One (S1) commented:

I'm more willing to look at home and go "What can we create with what we have", rather than starting with a recipe and going out and buying everything. I'm more flexible. I've learned that from watching [the cooking specialist].

Another (S5) commented: "For me personally, it's given me more confidence".

Time was another element mentioned by volunteers as affected by their involvement in the program. For some, this was a positive - it "keeps me occupied" was how it was seen by one 
volunteer (S2), while another (S4) observed:

My children are grown up and both have a master's degree. One is in education and one works with the government, so they have all grown up and I've got nothing to do!

However, for some volunteers the time demands were a less positive aspect of the program. Asked whether or not they would give more time if necessary, one (S1) agreed but drew attention to the impacts of volunteering on the tiredness of volunteers: "[I] would do it if necessary. I'd rather be tired doing something I believe in". Another (S2) said: "would if I could" but noted that she had "other commitments".

Volunteer overload was identified as a potential disadvantage of volunteers becoming so well known in the school, being visible and available and having their specific skills recognized and harnessed. One parent volunteer (S3) said:

And the thing is, if they know you've got computer skills, you get "Oh, I just want an invitation done for this" or "I just want a label made for this" or they know you use the printer a lot or the laminator, there are lots of "can you...?",

For one parent, volunteering in the program had been more time consuming than expected:

[I didn't know it would be so] time consuming; it's definitely time consuming. That's definitely negative; well, my part as a volunteer is extremely hard. (S3)

One issue that emerged in relation to the time demands on volunteers was the failure to recognize the difference between parents who are full-time homemakers and those who are 
self-employed and working from home. One volunteer from this latter category (S3) commented:

"I work from home and I have to make it obvious that I am working from home and it's not just hanging around. It's harder, I think, when you work from home to say no".

\section{Impacts on schools:}

Typically, schools identified a range of benefits flowing from the program (including from the voluntary aspects of the program), many of them revolving around an improved relationship between school and community (see also Block et al., 2011). One principal (PR4) observed that there was "terrific community awareness of the program". Another (PR1) noted that there was an "increased school profile" as a result of the program: "Families come to the school for the program".

Working in an area with a high migrant population, one principal (PR2) noted that the "program has improved connection with the Vietnamese community". In this principal's view, the language barrier which had made members of some migrant communities uncomfortable volunteering in the class room has been overcome in the garden and kitchen. Another principal (PR3) commented:

\section{Community connectedness [is one of the most important outcomes].}

Other school-level benefits noted were: increased engagement of students, heightened cooperation and a new level of communication within the school. One principal (PR4) observed:

The program speaks for itself. [It] has refreshed the school; everyone looks forward to doing it. 


\section{Impacts on the SAKG program itself:}

While the program is built around hands-on volunteers, the importance of voluntary contributions expressed in other forms may not always be so widely recognized. In particular, the voluntary contributions of money, labor and other resources have been crucial to the establishment and ongoing sustainability of the program in many schools. Comments by school principals highlighted both the importance and the recognition of voluntary contributions. One (PR3) noted:

[The program] needs significant fundraising; this year $\$ 4,000$ so far raised.

Another (PR2) commented:

[We are] struggling to get sufficient volunteer support from parents. [We] have once had to shut one work station in the kitchen due to insufficient volunteer help. [We] have put up posters with the message that if you want your child to have this program you need to volunteer. ... [We] rely on volunteers from local ANZ bank and Ardoch.

A group of parent volunteers from one of the schools (S3) similarly highlighted the dependence of the program on voluntary inputs:

The four of us especially have all realized they need some support for this kitchen garden program, being that our funding runs out at the end of this year. So we ran this bloody fair and that was six months of my life and that's what I gave up to ensure that my children still have this program in their school.

Various strategies were suggested to address the difficulties in gaining sufficient voluntary 
contributions (whether financial, material or time inputs). These included: involving the corporate sector to a greater degree, appealing to parents and/or the local community, providing guidance on how to obtain such support and giving parents the choice of either volunteering or contributing a levy. One parent/volunteer (S3) commented:

What we did in Holland, at the start of the year, we sent out a letter saying that volunteering was compulsory but if you don't want to do it you can pay a levy.

Generally, however, parents/volunteers considered the program to be a high priority - one for which they would be willing to contribute more, both in financial and practical terms. One (S4) said: "As a community member I would pay a couple of hundred [dollars] to keep it". Another (S4) commented:

I would be feeling this is a priority if this were threatened. I would rearrange my life in that way for the program but I wouldn't feel it was a sacrifice.

4. Impacts on teachers and specialist staff:

There was strong support for the SAKG program from teachers, although there was little specific comment about the effects of volunteers/volunteering on teachers. It seems likely however, that improved communication with specific parent groups such as migrant populations (as noted above) would be beneficial to teachers by improving the relationships between class room teachers and school families.

Perhaps the greatest negative impact on teachers from the involvement of volunteers was the difficulty of ensuring that sufficient volunteers were available for each class, and facilitating and co-ordinating the input of volunteers. Generally, the 'rostering' of volunteers was not left 
to the classroom teacher, but was a role allocated to a specific person (in some cases a staff member and in other cases a volunteer). At one school, the principal (PR2) commented that the "assistant principal works hard to call parents and get volunteers". Managing the input of volunteers posed issues for some teachers. The participant observation in one school indicated that some volunteers were more comfortable with the children taking the lead with food preparation and cooking, while others (particularly those less experienced at the kitchen volunteer role) tended to have the children watching them do the work. The specialist staff needed skills in diplomacy to encourage volunteers to give the children the opportunity to perform the tasks, without putting the volunteers 'off-side'.

\section{Impacts on students:}

The children participating in the program were enthusiastic about having the volunteers involved. Children's comments suggested a range of impacts of the volunteers/volunteering on students, including: creation of opportunity, knowledge transfer, skill development, relationship building and enjoyment/fun. The pivotal role of volunteers in the program was acknowledged in the remark by one student (S1):

It's good they want to give up their time, we are really glad. We wouldn't have it [the program] if we didn't have volunteers.

Along the same lines, another (S4) stated “...we'd have no chance of doing it without them”.

The principal of one of the schools (PR1) highlighted the program's impacts on children in terms of expanding the range of people with whom they meet, observing that the program provides children with the opportunity "to interact with volunteers that they normally wouldn't". Children also recognized this benefit, with one (S6) observing that the best thing 
about the program was the chance to "meet new people ... and learn new things from them". Another child (S4) said: [I] "like working with new volunteers because each one is different".

From the children's perspective, a particularly positive aspect of the program was the opportunity to learn from the experience, skills and knowledge of volunteers as the following comment (S1) indicates:

They're good. You get experience from them, you can ask them stuff.

The prevailing very positive attitude of students towards volunteers was summed up in the following comments:

It's just more fun to have that really [referring to having parents and community members coming in as helpers]. (S3)

The volunteers are cool! (S2)

\section{Discussion}

Volunteers in the SAKG program in primary schools varied widely in the ways in which they became involved in the program. A very strong focus on individual drivers is evident in the literature around volunteer motivation. This begs the question as to whether these individual drivers should be classified as motivating factors or benefits, and where the line between motivations and benefits can or should be drawn. While some of the individual motivations highlighted in the Volunteer Function Inventory (VFI) such as opportunities to use existing skills or develop new skills (Anderson \& Cairncross, 2005) were evident in the SAKG program data, it was also apparent that some volunteers were motivated by less personally focused issues. For parents of children in the school, motivations such as a belief in the 
program, a desire to support the school and to ensure opportunities for enhancing children's development could obviously be traced back to individual benefit (albeit secondary - for their children), but for volunteers without children at the school, these motivations were much more likely to have an altruistic basis. For some volunteers however, it may be a false dichotomy to draw a distinction between individual gain and altruism. Some comments by volunteers seemed to suggest a more ecological model, where much of the reward and sense of purpose came from being part of a community and contributing to something important, and also the recognition of that by the community. It was clear from the views expressed in focus group discussions that, for some volunteers, there were multiple motivations for volunteering, and that the distinction between individualistic and altruistic motivations was blurred. The suggestion earlier in this paper of a model of volunteer motivation which includes three categories - altruistic, material and intangible - appears to be borne out by this study. For many of the non-parent volunteers in particular, their volunteering clearly includes an altruistic element. However, for others, access to material benefits such as skills training and vocational qualifications and even more informal acquisition of new knowledge were important. Intangible benefits such as feeling useful and appreciated and opportunities for social connection were also apparent in the SAKG data. It is not clear, however, to what extent these various elements were motivating factors or simply spin-off effects.

The literature on volunteering in general has a strong focus on the benefits flowing to volunteers (e.g. Black \& Living, 2004) but an examination of the literature on volunteering in schools reveals a very different emphasis - on the benefits volunteers and volunteering bring to schools (Brent, 2000; Sheldon \& Epstein, 2002) and to students (Williams, Thorogood \& Jones, 2002). This study, however, found that while there were clear benefits to schools and to students from the involvement of volunteers as part of the SAKG program, these benefits were complemented by benefits flowing to the volunteers. 
Despite diversity in the ways in which volunteers became involved with the program and in the roles they played, there were nevertheless some consistent findings in terms of the benefits experienced by volunteers. These included: an opportunity to use time in a way they saw as productive, an increased sense of belonging, both in the school community and the broader community, learning opportunities, an increased sense of self-worth and enjoyment.

For schools, the involvement of volunteers provided benefits in terms of: a higher level of engagement between the school and the local community, the opportunity to engage more effectively with groups otherwise difficult to reach, and an increased level of student engagement. In addition to these benefits, the involvement of volunteers improved the sustainability of the program, provided teachers with an opportunity for improved communication with members of minority ethnic groups within the school and/or local community, and gave students the chance to relate to new people, to learn from their experience and to have fun in working with the volunteers.

With no quantitative data collected on the demographics of volunteers involved in the program, it was not possible to discern whether or not the volunteer profile reflected the profile of volunteers in general or of 'typical' volunteers in schools as highlighted in the literature. However, anecdotally, while it appeared that the majority of volunteers did fit the profile of predominantly female, parents with children in the school, Australian born and English speaking (Brent, 2000; ABS, 2008), in the one school with a large number of CALD (Culturally and Linguistically Diverse) families, the program was seen as playing an important role in bringing these families into the school. Given this 'typical' pattern of volunteering, it was not surprising that the one school identified as having a culturally diverse population experienced difficulties in recruiting volunteers. While it was impossible to 
distinguish whether this was the result of cultural or socio-economic factors or a mix of the two, it was the view of the principal that the socio-economic factors were more important. This is an important issue that needs further exploration in school based volunteer research as it has implications for equity (and potentially for the establishment, funding and sustainability of programs in low SES areas). It appears to be supported by the fact that another school in rural Victoria where there was little ethnic variation in the population also experienced difficulty recruiting volunteers. There the principal attributed this difficulty to families facing chronic financial stress because of the drought. However, the same principal also noted that the nature of the program meant that even though a decision was made not to pursue fundraising options, support could be provided in a range of ways and even drought affected farmers were able to contribute gardening tools and manure for the garden. This was also reflected in comments from other principals that parents who have not provided fundraising or class-based volunteer support to the school in the past were happy to contribute other skills such as building and carpentry. It should also be noted that many of the teachers also reported contributing a significant amount of personal time to the development of the kitchen, the garden and the program and to fundraising efforts. This evaluation focused on volunteer experience in relation to the cooking and gardening classes so although some also reported their involvement in fundraising, the full range of volunteering experiences and contributions has not been captured and is more extensive than reported here.

Perhaps the most telling benefits to flow both to students and to volunteers were not the 'three Rs - reading, w'riting and a'rithmetic' but the three Cs - confidence, capabilities and connections. While the literature suggests that these benefits typically flow to students from volunteering programs in schools (e.g. Williams, Thorogood \& Jones, 2002), there is much less recognition in the literature of the two-way nature of the benefit flow indicated by the results of this study. 
There are other aspects also of this two-way flow, particularly in relation to the impact on the school. While schools sometimes reported feeling the strain of the need to recruit volunteers (and fundraise), it was also well-recognized that the community connectedness that flowed from this effort was one of the major benefits of the program. It is also worth noting that the school where the parents reported the greatest demands on them as volunteers was also the only school that had not tried to recruit non-parent volunteers. In fact these parent-volunteers were surprised to hear from us that other schools had done this. This highlights the need for sharing of experiences and ideas - the underlying purpose of this paper.

There is, however, a more challenging interpretation of the concept of volunteer input that this study has brought to light. The expectation tacit in the part-funding of the program from government makes volunteers a requirement and not something to be appreciated when freely donated. There are potential advantages in this approach if making volunteers essential to the success of the program results in a benefit to volunteers through feelings of being needed and valued. But there are also difficulties arising from the pressure on the school to arrange the volunteers and the pressure on volunteers to increasingly commit more and more of their time and effort. There is a sense of this in one principal's expressed view that volunteer input is a parental duty and not a freely-donated commodity, but also in volunteers' comments that suggested they were being pushed to do more than they really would freely have chosen to do. There was insufficient evidence in this study to explore whether this shift in expectations and perceptions has an impact on volunteer recruitment or the volunteer experience. However it is an important issue for future exploration. It is possible that introducing a system that assigns volunteering duty to parents may increase their participation and potentially their appreciation of the program. Conversely, the element of obligation could undermine both the altruistic aspects of volunteer motivation and the benefit of feeling appreciated. This may ultimately reduce the extent of participation and/or the two-way beneficial flow. 
Perhaps one way of enhancing the satisfaction of volunteers with their voluntary role in schools, and thereby improving the likelihood of volunteer recruitment and retention, is to undertake some matching of the motivations and desires of volunteers with the roles they are asked to fulfill. This would necessitate some research into the motivations of individual volunteers, in keeping with the findings of Jarvis (2007), but the cost-benefit outcomes may well be justified.

\section{Conclusions}

This study confirmed the findings of the literature review that, although motivations of volunteers may vary, it is not possible to classify volunteers on the basis of motivation into distinct categories of 'altruistic' or 'instrumental'. Likewise, the results of this study affirmed the findings of the literature review that volunteering has benefits for the social, psychological and physical health of volunteers. The dependence of school garden programs on voluntary community input, as noted in the literature, was confirmed. The findings of this study indicate that sustaining innovations such as the SAKG program in primary schools requires a 'whole of community' effort. Early indications are that, while most schools can raise the funds, resources and community support to establish the program, some schools struggle with recruiting and retaining sufficient volunteers to ensure the program's maximum effectiveness. Some schools perceived parent involvement as a duty. It is not clear to what extent this influences recruitment methods or volunteering experience. However, it could inadvertently undermine volunteer motivations and the multiple benefits for all arising from the volunteering aspect of the program. Longitudinal research is needed to explore the likelihood of any change in community commitment over time, including any decline in volunteering which might threaten the viability of the SAKG program. Consideration should be given to promoting the program beyond the immediate school families to encourage broader community involvement. The mutual benefits for all of volunteer involvement in the 
program, particularly in terms of the 'three Cs' - confidence, capabilities and connections, should be highlighted as a way of encouraging volunteer support and increasing the sustainability of the program.

\section{Notes}

a Through the inclusion of 'learning stories' on its website, the Stephanie Alexander Kitchen Garden Foundation enables schools and others involved in its programs to share information which may help to answer the 'can you' questions identified in this research.

\section{References}

Anderson, E. \& Cairncross, G. (2005), Understanding and managing volunteer motivation: Two regional tourism cases, Australian Journal on Volunteering 10(2): 7-17. Australian Bureau of Statistics (2011), Voluntary Work, Australia 2010, ABS, Canberra Australian Bureau of Statistics (2008), Australian Social Trends 2008: Voluntary Work, ABS, Canberra

Australian Bureau of Statistics (2006), Voluntary Work, Australia, ABS, Canberra Australian Council of Social Service (ACOSS) (1996), Volunteering in Australia, ACOSS Paper No. 74, Sydney.

Bauch, P.A. \& Goldring, E.B. (2000), Teacher Work Context and Parent Involvement in Urban High Schools of Choice, Educational Research and Evaluation 6(1): 1-23

Berlinic, K. (2006), School Community Gardens: School Ground Greening, Saskatchewan School Boards Association Research Report \#07-06

Black, W. \& Living, R. (2004), Volunteerism as an Occupation and its Relationship to Health and Wellbeing, British Journal of Occupational Therapy 67(12): 526- 
Block, K., Gibbs, L., Staiger, P., Gold, L., Johnson, B., Macfarlane, S., Townsend, M. \& Long, C. (2011), Growing Community: the Impact of the Stephanie Alexander Kitchen Garden Program on the Social and Learning Environment in Primary Schools, Health, Education and Behavior. DOI:1090198111422937, 2011

Block, K., Gibbs, L., Johnson, B., Staiger, P., Townsend, M., Macfarlane, S. \& Gold, L. (2009), Evaluation of the Stephanie Alexander Kitchen Garden Program - Final Report to The Stephanie Alexander Kitchen Garden Foundation, McCaughey Centre, September 2009, http://www.kitchengardenfoundation.org.au/about-the-program/proving-it-works

Brent, B.O. (2000a), What You Never Knew about School Volunteers, The Education Digest October 2000 pp. 55-59

Brent, B.O. (2000b), Do Schools Really Need More Volunteers? Educational Policy 14: 494510

Carpenter, J. \& Meyers, C.K. (2010), Why volunteer? Evidence on the role of altruism, image, and incentives, Journal of Public Economics 94: 911-920

Clary, E.G. \& Snyder, M. (1999), The motivations to volunteer: Theoretical and practical considerations, Current Directions in Psychological Science 8(5): 156-159.

Cutter-Mackenzie, A. (2009), Multicultural School Gardens: Creating Engaging Garden Spaces in Learning about Language, Culture, and Environment, Canadian Journal of Environmental Education 14: 122-135

Drummond, C. (2008), The complexities of attracting and retaining volunteers in school canteens, and their impact on healthy food provision, Australian Journal on Volunteering 13(1): 39-47

Flick, M., Bittman, M. \& Doyle, J. (2002), The community's most valuable [hidden] assetVolunteering in Australia, Social Policy Research Centre, University of New South Wales Gibbs, L., Staiger, P.K., Townsend, M., Macfarlane, S., Waters, E., Gold, L., Block, K., Johnson, B., Kulas, J., Ukoumunne, O.C. (2012), Sampling and Methodology for the Evaluation of the Stephanie Alexander Kitchen Garden Program, Health Promotion 
Journal of Australia (under review - submitted 8 February 2012)

Gonski, D., Boston, K., Greiner, K., Lawrence, C., Scales, B. \& Tannock, P. (2011), Review of Funding for Schooling - Final Report, Australian Government, Canberra

Harrison, S. (2008), School Food Gardens in Multicultural Inner-city Settings, Green

Teacher 84: 24-28

Hazzard, E.L., Moreno, E., Beall, D.L. \& Zidenberg-Cherr, S. (2011), Best Practices

Models for Implementing, Sustaining, and Using Instructional School Gardens in

California, Journal of Nutrition Education and Behavior 43(5): 409-413

Huntsinger, C.S. \& Jose, P.E. (2009), Parental involvement in children's schooling:

Different meanings in different cultures, Early Childhood Research Quarterly 24: 398410

Institute for Volunteering Research (2005), Unlocking the potential? Reviewing the Wildlife Trusts' project to strengthen volunteering, Institute of Research Volunteering, Research Bulletin.

Jarvis, S. (2007), Recruitment and retention of volunteers, Volunteer Development Scotland

Kim, Y. (2009), Minority parental involvement and school barriers: Moving the focus away from deficiencies of parents, Educational Research Review 4: 80-102

Kirby, T. (2008), A Garden of Learning, Science and Children Summer 2008: 28-31

Li, Y. \& Ferraro, K.F. (2006), Volunteering in Middle and Later Life: Is Health a Benefit, Barrier or Both? Social Forces 85(1): 497-519

Narushima, M. (2005), Payback time: community volunteering among older adults as a transformative mechanism, Ageing \& Society 25: 567-584

O’Brien, L., Townsend, M. \& Ebden, M. (2010), Doing Something Positive: Volunteers' Experiences of the Well-Being Benefits Derived from Practical Conservation Activities in Nature, Voluntas 21:525-545

O’Brien, L., Burls, A., Townsend, M. \& Ebden, M. (2011), Volunteering in nature as a way 
of enabling people to reintegrate into society', Perspectives in Public Health 131(2): 7181

Ozer, E.J. (2007), 'The Effects of School Gardens on Students and Schools: Conceptualization and Considerations for Maximizing Healthy Development, Health Education \& Behavior 34(6): 846-863

Phillips, L.C. \& Phillips, M.H. (2010), Volunteer Motivation and Reward Preference: An Empirical Study of Volunteerism in a Large, Not-For-Profit Organization, SAM Advanced Management Journal Autumn 2010: 12-19 \& 39

Ralston, S. (2011), It Takes a Garden Project: Dewey and Pudup on the Politics of School Gardening, Ethics \& the Environment 16(2)

Ross, J. (2011), A million education volunteers, The Australian Higher Education Supplement, $3^{\text {rd }}$ December 2011

Rotolo, T \& Wilson, J. (2006), Employment sector and volunteering: The contribution of nonprofit and public sector workers to the volunteer labour force, The Sociological Quarterly 47: 21-40.

Ruiter, S. \& De Graaf, N.D. (2006), National context, religiosity, and volunteering: results from 53 Countries, American Sociological Review 71: 191-210.

Scottish Natural Heritage (2007), Volunteering in the natural heritage; an audit and review of natural heritage volunteering in Scotland. Commissioned report no. 219, Scottish Natural Heritage, Clydebank.

Sheldon, S.B. \& Epstein, J.L. (2002), Improving Student Behavior and School Discipline with Family and Community Involvement, Education and Urban Society 35(1): 4-26

Tan, E.T. \& Goldberg, W.A. (2009), Parental school involvement in relation to children $\square$ s grades and adaptation to school, Journal of Applied Developmental Psychology 30: 442453

Townsend, M. (2006), Feel Blue? Touch Green! Participation in forest/woodland 
management as a treatment for depression, Urban Forestry \& Urban Greening, Vol. 5, pp. 111-120

Williams, M., Thorogood, L. \& Jones, D. (2002), How School Volunteers can Help to Raise Standards and Enthusiasm for Literacy, Early Child Development and Care 172(4): 371377

\footnotetext{
'Nvlvo: Software designed for qualitative and mixed methods research data analysis. http://www.qsrinternational.com/products_nvivo.aspx

ii Ardoch Youth Foundation: a not for profit organisation in Australia that links schools, corporate organisations and communities, generating resources to support and facilitate projects that assist young people and their families, including those experiencing disadvantage, to be in school.
} 